\title{
GMR
}

\section{Effect of acute/subchronic samarium exposure on the concentration, motility, and morphology of sperm in male mice}

\author{
D.Y. Zhang ${ }^{1}$, X.Y. Shen ${ }^{2}$, X.L. Xu' ${ }^{1}$ Q. Ruan ${ }^{3}$, SS. Hu ${ }^{3}$, Y.Y. Chen ${ }^{3}$ and \\ Z.M. Wang ${ }^{1}$ \\ ${ }^{1}$ College of Biology and Environmental Engineering, \\ Zhejiang Shuren University, Hangzhou, China \\ ${ }^{2}$ College of Biology and Chemical Engineering, \\ Zhejiang University of Science and Technology, Hangzhou, China \\ ${ }^{3}$ College of Biology and Chemistry, Zhejiang Normal University, \\ Jinhua, China
}

Corresponding author: X.Y. Shen

E-mail: 66956774@qq.com

Genet. Mol. Res. 15 (2): gmr.15028807

Received May 16, 2016

Accepted June 3, 2016

Published June 21, 2016

DOI http://dx.doi.org/10.4238/gmr.15028807

\begin{abstract}
Male ICR mice were orally administered samarium nitrate $\left[\mathrm{Sm}\left(\mathrm{NO}_{3}\right)_{3}\right]$ to investigate its effects on sperm concentration and sperm quality. After acute exposure to $\geq 2880.00 \mathrm{mg} / \mathrm{kg} \mathrm{Sm}\left(\mathrm{NO}_{3}\right)_{3}$ via intragastric gavage, sperm motility and acrosome integrity were decreased, and the sperm malformation percentage was increased $(\mathrm{P}<0.05)$. After subchronic exposure to $\geq 500.00 \mathrm{mg} / \mathrm{L} \mathrm{Sm}\left(\mathrm{NO}_{3}\right)_{3}$ administered via drinking water for 90 days, relative gonad weight, sperm concentration, and sperm quality significantly decreased $(\mathrm{P}<0.05)$. Sperm malformation also increased after subchronic exposure to $\mathrm{Sm}$, which was found to be the most sensitive index. Sperm head malformation accounted for the largest proportion of all types of sperm malformations evaluated. Of the six different
\end{abstract}


subtypes of head malformation, irregular shape accounted for the largest proportion.

Key words: Samarium nitrate; Male mice; Sperm concentration; Sperm quality; Sperm malformation

\section{INTRODUCTION}

Rare earth elements (REEs) are a group of metals comprising yttrium, 14 lanthanide elements, and scandium. In addition to their industrial usage, REEs have been used directly in humans for magnetic resonance diagnostic imaging and in therapies for cancers and synovitis. Therefore, extensive studies are warranted to evaluate the risks associated with exposure to REEs. Mortality studies in mammals indicated that most REEs are not highly toxic. The $50 \%$ lethal dose $\left(\mathrm{LD}_{50}\right)$ values for intravenously and intraperitoneally injected REEs range from 10 to $100 \mathrm{mg} / \mathrm{kg}$ body weight (BW) and 150 to $700 \mathrm{mg} / \mathrm{kg} \mathrm{BW}$, respectively (Hirano and Suzuki, 1996).

Damage caused by REEs has been confirmed in different organs of mammals, such as in the liver, lungs, kidneys, spleen, gastrointestinal tract, and bone (Hirano and Suzuki, 1996). REEs are also toxic for the reproductive system in both male and female mammals. Subcutaneous injection of $\mathrm{Ce}^{3+}$ at $80 \mathrm{mg} / \mathrm{kg} \mathrm{BW}$ into mice during pregnancy or the lactation period was found to reduce the body weight of the offspring (D'Agostino et al., 1982). Intraperitoneal injection of $\mathrm{La}^{3+}$ at $44 \mathrm{mg} / \mathrm{kg} \mathrm{BW}$ increased the rate of miscarriage and decreased the average litter size of pregnant mice (Abramczuk, 1985). Intratesticular injection of REEs caused degeneration of the seminiferous epithelium and the interstitium (Kamboj and Kar, 1964). Subcutaneous administration of $\mathrm{Ce}^{3+}$ revealed that the testes are one of the main targeted organs for REE deposition (Morganti et al., 1978). Our previous study also indicated that the testes are one of the targeted organs of samarium (Sm) administrated orally in male mice. Subchronic exposure to Sm caused lesions and abnormal regulation of apoptosis in the testis (Zhang et al., 2014). A recent investigation of human semen also suggested that $\mathrm{La}, \mathrm{Ce}, \mathrm{Gd}$, and $\mathrm{Ca}$ concentrations in the semen are negatively associated with sperm concentration, and positively associated with the progressive motility and percentage of normal spermatozoa (Marzec-Wróblewska et al., 2015).

However, the male reproductive toxicity of REEs and their mechanism of action are still poorly understood. In addition, most previous studies have administered REEs at parenteral dosages for toxicity evaluation. Therefore, it is important to assess how exposure to subchronic levels of Sm, a rarely assessed REE, affects sperm in mice. The aim of this study was to evaluate the effects of acute or subchronic exposure to $\mathrm{Sm}$ on the concentration and quality of sperm in male mice.

\section{MATERIAL AND METHODS}

\section{Animals}

Healthy male ICR mice were provided by Zhejiang Provincial Center of Experimental Animals, China. Six-week old mice (BW $25.4 \pm 2.2$ g) and 3.5-week-old mice (BW 13.85 $\pm 0.07 \mathrm{~g}$ ) were used for the acute and subchronic exposure experiments, respectively. The animals were housed in an environmentally controlled $\left(25^{\circ} \pm 1^{\circ} \mathrm{C} 55 \pm 5 \%\right.$ humidity; $12-\mathrm{h}$ light/dark cycle) room with free access to food and water. 


\section{Acute exposure experiment}

Animals were divided randomly into 7 groups, with 10 animals per group for exposure to $0.00,2000.00,2400.00,2880.00,3456.00,4147.20$ and $4976.64 \mathrm{mg} / \mathrm{kg}$ samarium nitrate $\left[\mathrm{Sm}\left(\mathrm{NO}_{3}\right)_{3}\right]$, respectively. $\mathrm{Sm}\left(\mathrm{NO}_{3}\right)_{3}$ was administrated by gavage a total of 4 times at 2 -h intervals. The consciousness, spontaneous activity, ingestion, and death of the animals were recorded for 7 days in total. The $\mathrm{LD}_{50}$ was calculated according to the improved Karber method (Goldstein and Jacobsen, 1988). Finally, all of the animals were killed via cervical vertebra luxation (with prior anesthesia) for analysis of relative organ weight, sperm concentration, and sperm quality.

\section{Subchronic exposure experiment}

The mice were divided randomly into 5 groups, with 20 animals per group, for 90 days of $\mathrm{Sm}\left(\mathrm{NO}_{3}\right)_{3}$ exposure via their drinking water. The dose of $\mathrm{Sm}\left(\mathrm{NO}_{3}\right)_{3}$ for each group was established as $0.00,5.00,50.00,500.00$ and $2000.00 \mathrm{mg} / \mathrm{kg}$, respectively. For each animal, $7 \mathrm{~mL} \mathrm{Sm}\left(\mathrm{NO}_{3}\right)_{3}$ solution was given per day. Finally, the animals were killed in the same manner as described above for analyzing relative organ weights, sperm concentration, and sperm quality.

\section{Evaluation of relative organ weight}

After the acute/subchronic exposure to Sm, the testes, epididymis, liver, and spleen were isolated and weighed. The relative organ weight was defined as the ratio of organ weight (mg) to BW (g).

\section{Evaluation of sperm concentration and sperm motility}

The epididymis was isolated, sheared, and filtered for suspension preparation using physiological saline. Sperm counting and sperm motility evaluation were performed at $25^{\circ} \mathrm{C}$ using a phase-contrast microscope (OLYMPUS CX41, Japan) with a chamber of 25 x 16 grids. For sperm motility evaluation, 200 sperm from each group were observed. The motility of the sperm was divided into 4 levels (I-IV) according to swimming activity (WHO, 1999), and sperm activity (\%) was calculated as: [(I + II + III)/(I + II + III + IV)] x 100.

\section{Analysis of sperm malformation}

Three semen smears were prepared for each animal. From each smear, 400 sperms were observed with a microscope. Sperm malformation was assessed according to a previous report (China National Standardization Management Committee, 2003). For sperm acrosome integrity analysis, sperm smears were prepared in accordance with the Giemsa staining method for microscopy. Two hundred sperm were observed for each smear. According to injury location, sperm malformation was divided into four types: head, neck, body, tail, and multiple parts. Sperm head malformation was further divided into 6 subtypes: fat-head shape, banana shape, irregular shape, hook-missing shape, double-head shape, and small-head shape. 


\section{Statistical analysis}

One-way analysis of variance with Duncan's multiple comparisons test was employed to detect statistical differences between the Sm-treated and negative control groups using the SPSS (V13.0) software.

\section{RESULTS}

\section{Acute exposure experiment}

\section{Poisoning manifestations and $L D_{50}$}

As the Sm dose increased, the mortality increased from $0 \%(0 / 10), 0 \%(0 / 10), 0 \%$ $(0 / 10), 10 \%(1 / 10), 50 \%(5 / 10), 100 \%(10 / 10)$, and 100\% (10/10). Most deaths occurred within $24 \mathrm{~h}$ after exposure. Typical symptoms observed included depression, a curled-up body, an arched back, disheveled hair, gait instability, breathing difficulties, and quiet death. Two dead mice in the $4976.64 \mathrm{mg} / \mathrm{kg}$ group showed phallorrhagia. Autopsy of most dead mice showed a swollen liver and an enlarged stomach. Most of the animals that survived regained their appetite 3-4 days after exposure. Most of the treated animals showed poor growth until 6 days after exposure. Finally, the $\mathrm{LD}_{50}$ was calculated as $3393.56 \mathrm{mg} / \mathrm{kg}$, with a $95 \%$ confidence interval of $3175.50-3626.60 \mathrm{mg} / \mathrm{kg}$.

\section{Relative organ weight}

Most of the mice treated with Sm showed renal atrophy, splenomegaly, and atrophy of the testis and epididymis. The relative organ weights of the surviving mice are summarized in Table 1. Statistical significance was confirmed for relative kidney weight in all of the treated groups, and for relative spleen weight in the $2880 \mathrm{mg} / \mathrm{kg}$ dose group $(\mathrm{P}<0.05)$. The mean relative organ weights of the testis and epididymis were decreased in all of the treated groups compared with the negative control group, although no statistical significance was confirmed.

Table 1. Relative organ weight after acute exposure to Sm (means $\pm \mathrm{SD}$ ).

\begin{tabular}{l|c|c|c|c|c|c}
\hline \multirow{2}{*}{$\mathrm{Sm}\left(\mathrm{NO}_{3}\right)_{3}(\mathrm{mg} / \mathrm{kg})$} & \multicolumn{5}{|c}{ Relative organ weight } \\
\cline { 2 - 7 } & Testis & Epididymis & Liver & Kidney & Spleen & Lung \\
\hline 0.00 & $6.77 \pm 1.00$ & $1.86 \pm 0.20$ & $72.54 \pm 6.67$ & $17.17 \pm 1.43$ & $3.51 \pm 0.54$ & $5.87 \pm 0.72$ \\
\hline 2000.00 & $6.75 \pm 1.15$ & $1.78 \pm 0.22$ & $72.48 \pm 7.59$ & $15.96 \pm 1.25^{*}$ & $3.36 \pm 0.43$ & $5.64 \pm 0.30$ \\
\hline 2400.00 & $6.42 \pm 0.58$ & $1.77 \pm 0.22$ & $74.09 \pm 9.84$ & $15.71 \pm 0.89^{*}$ & $3.70 \pm 0.54$ & $5.92 \pm 0.76$ \\
\hline 2880.00 & $5.96 \pm 0.33$ & $1.72 \pm 0.20$ & $72.78 \pm 8.61$ & $15.63 \pm 0.97^{*}$ & $4.17 \pm 0.65^{* *}$ & $5.64 \pm 0.86$ \\
\hline
\end{tabular}

$* \mathrm{P}<0.05 ; * * \mathrm{P}<0.01$.

\section{Sperm concentration and motility}

The results of sperm concentration and motility are summarized in Table 2. The Smtreated groups all showed decreased mean values of sperm concentration and sperm motility compared with the negative control group. A statistically significant difference in sperm motility was confirmed between the $2880 \mathrm{mg} / \mathrm{kg}$ group and the negative control group $(\mathrm{P}<0.05)$. 
Table 2. Sperm concentration and sperm quality after acute exposure to $\mathrm{Sm}$ (means $\pm \mathrm{SD}$ ).

\begin{tabular}{l|c|c|c|c}
\hline \multirow{2}{*}{$\mathrm{Sm}\left(\mathrm{NO}_{3}\right)_{3}(\mathrm{mg} / \mathrm{kg})$} & \multicolumn{4}{|c}{ Sperm quality } \\
\cline { 2 - 5 } & Concentration $\left(10^{6 / \mathrm{mL})}\right.$ & Motility (\%) & Malformation (\%) & Acrosome integrity (\%) \\
\hline 0.00 & $3.89 \pm 1.85$ & $50.68 \pm 9.38$ & $11.87 \pm 1.88$ & $94.87( \pm 2.23)$ \\
\hline 2000.00 & $3.28 \pm 1.57$ & $45.69 \pm 8.33$ & $13.12 \pm 1.75$ & $93.55( \pm 3.47)$ \\
\hline 2400.00 & $3.61 \pm 1.79$ & $43.62 \pm 8.47$ & $14.61 \pm 3.13$ & $91.07( \pm 3.48)$ \\
\hline 2880.00 & $2.58 \pm 1.29$ & $40.23 \pm 6.93^{*}$ & $15.73 \pm 3.40^{*}$ & $88.99( \pm 4.91)^{*}$ \\
\hline
\end{tabular}

$* \mathrm{P}<0.05$.

\section{Sperm malformation and acrosome integrity}

As shown in Table 2, all of the Sm-treated groups showed increased mean values of sperm malformation percentage and decreased acrosome integrity percentage compared with the negative control group. A statistically significant difference was confirmed for the 2880 $\mathrm{mg} / \mathrm{kg}$ group $(\mathrm{P}<0.05)$.

\section{Subchronic exposure experiment}

\section{Relative organ weight}

As shown in Table 3, all of the treated groups showed decreased relative organ weight of the testis and epididymis compared with the negative control group. Statistical significance $(\mathrm{P}<0.05)$ was confirmed for the $500 \mathrm{mg} / \mathrm{L}$ group and the $2000 \mathrm{mg} / \mathrm{L}$ group. In addition, visible shrinking and hardening of the testis were also observed for some samples in the $2000 \mathrm{mg} / \mathrm{L}$ group (data not shown).

Table 3. Relative organ weight after subchronic exposure to $\mathrm{Sm}$ (means $\pm \mathrm{SD}$ ).

\begin{tabular}{l|c|c|c|c|c}
\hline \multirow{2}{*}{$\mathrm{Sm}\left(\mathrm{NO}_{3}\right)_{3}(\mathrm{mg} / \mathrm{kg})$} & \multicolumn{5}{|c}{ Relative organ weight } \\
\cline { 2 - 7 } & Testis & Epididymis & Liver & Kidney & Lung \\
\hline 0.00 & $5.98 \pm 0.34$ & $2.49 \pm 0.24$ & $52.22 \pm 7.83$ & $17.81 \pm 2.38$ & $5.53 \pm 0.61$ \\
\hline 5.00 & $5.93 \pm 0.48$ & $2.39 \pm 0.33$ & $53.97 \pm 8.07$ & $17.67 \pm 1.77$ & $5.63 \pm 0.98$ \\
\hline 50.00 & $5.87 \pm 0.50$ & $2.34 \pm 0.39$ & $57.45 \pm 4.18$ & $18.46 \pm 1.57$ & $5.36 \pm 0.36$ \\
\hline 500.00 & $5.80 \pm 0.48^{*}$ & $2.23 \pm 0.27^{*}$ & $49.87 \pm 6.57$ & $18.58 \pm 1.10$ & $5.18 \pm 0.64$ \\
\hline 2000.00 & $5.42 \pm 0.35^{*}$ & $2.21 \pm 0.31^{*}$ & $44.81 \pm 8.02^{*}$ & $20.32 \pm 2.05^{*}$ & $4.88 \pm 0.94$ \\
\hline \multirow{2}{*}{$* 0.05}$.
\end{tabular}

\section{Sperm concentration and sperm motility}

As shown in Table 4, the sperm quantity in all treated groups was lower than that in the negative control group. Statistical significance $(\mathrm{P}<0.01)$ was observed for the $2000 \mathrm{mg} / \mathrm{L}$ group, which demonstrated a $47.27 \%$ mean decrease in sperm concentration. The motility percentage of the sperm in all treated mice was lower than that of the negative control group. The decrease in sperm motility also showed a positive correlation with the Sm dose. Statistical significance $(\mathrm{P}<0.01)$ was observed for the $2000 \mathrm{mg} / \mathrm{L}$ group, with a mean $45.42 \%$ decrease in sperm motility. 
Table 4. Sperm concentration and quality after subchronic exposure to Sm (means $\pm \mathrm{SD}$ ).

\begin{tabular}{l|c|c|c|c}
\hline \multirow{2}{*}{$\mathrm{Sm}\left(\mathrm{NO}_{3}\right)_{3}(\mathrm{mg} / \mathrm{kg})$} & \multicolumn{3}{|c}{ Sperm quality } \\
\cline { 2 - 5 } & Concentration $\left(10^{6} / \mathrm{mL}\right)$ & Motility (\%) & Malformation (\%) & Acrosome integrity $(\%)$ \\
\hline 0.00 & $12.46 \pm 4.51$ & $57.60 \pm 8.64$ & $11.57 \pm 1.71$ & $93.68( \pm 2.18)$ \\
\hline 5.00 & $11.26 \pm 1.71$ & $56.88 \pm 18.96$ & $12.29 \pm 1.37$ & $92.83( \pm 2.84)$ \\
\hline 50.00 & $10.57 \pm 1.77$ & $53.52 \pm 19.2$ & $13.71 \pm 2.83^{*}$ & $91.50( \pm 3.08)^{*}$ \\
\hline 500.00 & $11.43 \pm 2.74$ & $48.24 \pm 14.88$ & $15.75 \pm 2.86^{* *}$ & $90.25( \pm 2.69)^{*}$ \\
\hline 2000.00 & $6.57 \pm 3.14^{* *}$ & $31.44 \pm 22.56^{* *}$ & $17.37 \pm 2.29^{* *}$ & $89.70( \pm 4.91)^{* *}$ \\
\hline$* \mathrm{P}<0.05 * * * \mathrm{P}<0.01$
\end{tabular}

\section{Sperm malformation}

As shown in Table 4, subchronic Sm exposure increased the sperm malformation percentages in all of the treated groups. Statistical significance $(\mathrm{P}<0.01)$ was confirmed for doses $\geq 50 \mathrm{mg} / \mathrm{L}$. A positive correlation between Sm dose and the malformation rate of sperm was also confirmed.

Physical malformation of the mouse sperm as a result of Sm exposure was observed in the head, neck, body, tail, or in multiple parts of the sperm. Figure 1 summarizes the observed sperm malformations. In the $50 \mathrm{mg} / \mathrm{L}$ group, malformation of the sperm body exceeded that observed in the negative control $(\mathrm{P}<0.05)$. In the $500 \mathrm{mg} / \mathrm{L}$ group, malformations of the sperm neck, body, tail, or multiple parts were all greater than malformations observed in the negative control $(\mathrm{P}<0.05)$. In the $2000 \mathrm{mg} / \mathrm{L}$ group, all types of malformations were more frequent than those observed in the control group $(\mathrm{P}<0.05)$. The $5 \mathrm{mg} / \mathrm{L}$ group displayed no statistically significant difference in the malformations from the negative control.

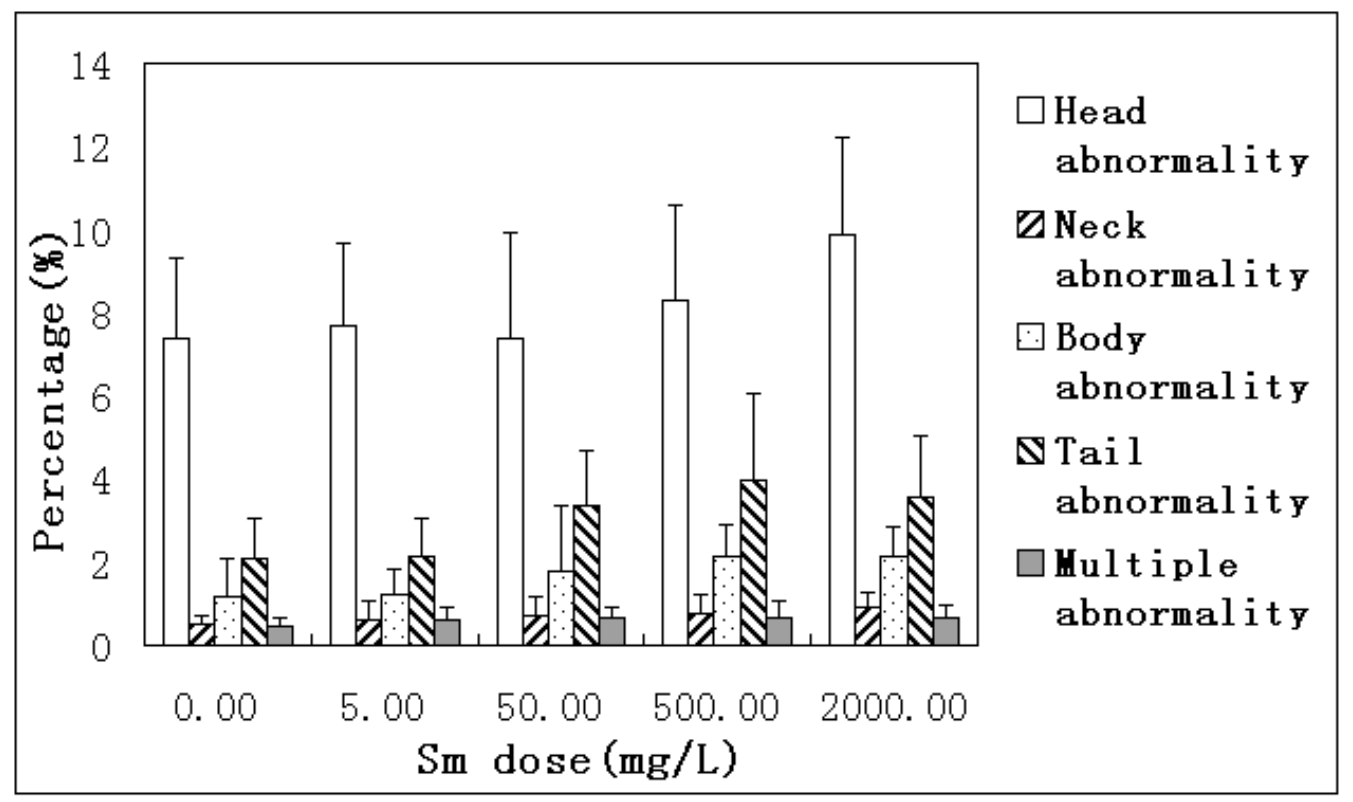

Figure 1. Sperm malformation percentage in each group. 
Overall, the results indicated that of the four types of sperm malformation, sperm head malformation accounted for the largest proportion. Of the six subtypes of sperm head malformation, irregular head shape accounted for the largest proportion, followed by bananashaped heads, missing hooks, and double-head malformation. Furthermore, the $2000 \mathrm{mg} / \mathrm{L}$ group showed a dramatic increase in irregular shape and small head malformations compared to the other groups.

\section{Integrity of the sperm acrosome}

As shown in Table 4, the percentage of sperm with acrosomal integrity was reduced in all of the Sm-treated groups compared to the negative control group. Statistical significance was confirmed for the 50,500, and $2000 \mathrm{mg} / \mathrm{L}$ groups $(\mathrm{P}<0.05)$.

\section{DISCUSSION}

Sm has been proven to cause testis injury in male mice (Zhang et al., 2014). In the present study, acute/subchronic exposure of Sm was further confirmed to affect the concentration and quality of sperm in male mice. In the acute experiment, it is uncertain if the injury to the gonads was directly caused by Sm, because injury in other organs was also extensively observed. After subchronic exposure to $\mathrm{Sm}(\geq 50 \mathrm{mg} / \mathrm{L})$, relative gonad weight, sperm motility, and acrosome integrity were decreased, and the sperm malformation percentage was increased; the sperm malformation percentage showed the greatest sensitivity to Sm exposure. The dose range of Sm used in this experiment, 5-2000 mg/L, was determined according to both the calculated $\mathrm{LD}_{50}$ value in this study and a previous investigation. An investigation on humans in USA showed that overall exposure was $0.71-34.5 \mathrm{ng} / \mathrm{L}$ and $3.55-$ $8.01 \mathrm{mg} / \mathrm{L}$ dissolved Sm and suspended Sm, respectively (Finney, 1978).

Sperm concentration reflects the fecundity capacity of male animals. Investigation of human semen indicated that the concentration of REEs in semen is negatively associated with sperm concentration (Marzec-Wróblewska et al., 2015). The observations in this study seem to support this. Spermatogenesis is a complicated physiological process in the testis. Decreases in sperm concentration are generally thought to be related to poor growth and development of spermatogenic cells. A previous study confirmed that subchronic exposure to $\mathrm{Sm}$ in male mice caused damage and increased the apoptosis percentage in the testis (Zhang et al., 2014).

Sperm activity indicates the effective fertilization potential of animals. In this study, $\mathrm{Sm}$ was confirmed to decrease sperm activity. The mechanism may be related to both the direct and indirect effects of $\mathrm{Sm}$. $\mathrm{La}^{3+}$ and $\mathrm{Eu}^{3+}$ can inhibit sperm motility in vitro, and the mechanism was suggested to be related to blocking of the $\mathrm{Ca}^{2+}$-binding site on the sperm membrane and inhibiting the formation of 3'5'-cAMP (Lee et al., 1981). $\mathrm{CeCl}_{3}$ can damage human sperm DNA dramatically, and the injury may be associated with oxidative stress and damage to the blood-testis barrier, causing disorder and dysfunction in testicular cells and the vascular system (Chen et al., 2015). In addition, a possible positive association between certain REEs and sperm progressive motility has also been reported, which remains poorly understood (D'Agostino et al., 1982).

Concerning the increased sperm malformation percentage in the subchronic exposure experiment, the mechanism is still unknown. The development and formation of sperm is controlled by certain genes in both autosomal and sex chromosomes in germ cells. In general, 
sperm malformation caused by chemicals is thought to be related to rearrangement and/or translocation of certain chromosomes. The decreased acrosome integrity percentage observed in this study indicates that subchronic exposure to Sm decreases the fertilization capacity of sperm, since the acrosomal reaction is an indispensable step for the sperm to enter an egg cell.

With regards to the interaction between REEs and biological molecules or cells, previous studies have indicated that REE ions may function as $\mathrm{Ca}^{2+}$ antagonists. The radius of REE ions is similar to that of $\mathrm{Ca}^{2+}$, which plays an important role in signaling pathways (Hirano and Suzuki, 1996). Intravenous injection of $\mathrm{YCl}_{3}, \mathrm{TbCl}_{3}, \mathrm{HoCl}_{3}$, and $\mathrm{YbCl}_{3}$ caused focal necrosis with $\mathrm{Ca}^{2+}$ deposition in rats (Hirano and Suzuki, 1996). The inhibitory effects of $\mathrm{La}^{3+}$ and $\mathrm{Tm}^{3+}$ on $\mathrm{K}^{+}$- or noradrenaline-induced contractile responses have also been demonstrated in rats; the mechanism may be related to displacing of membrane-bound $\mathrm{Ca}^{2+}$ (Triggle and Triggle, 1976). $\mathrm{Tb}^{3+}$ can bind to $\mathrm{Ca}^{2+}$-binding sites of the intestinal brush-border membrane (Loscalzo and Rabkin, 1986). Lanthanoids are also known to bind to $\mathrm{Ca}^{2+}$ - or $\mathrm{Mg}^{2+}$-binding sites of calmodulin, and to cystatin, phosphatidylserine, and ATPase in the sarcoplasmic reticulum (Buccigross and Nelson, 1986; Fujimori and Jencks, 1990). $\mathrm{La}^{3+}$ also inhibits the $\mathrm{Ca}^{2+}$-dependent release of chemical mediators such as catecholamine from the adrenal medulla and histamine from mast cells (Weiss, 1974). Sm has been confirmed to accumulate in the mitochondria, which is particularly susceptible to $\mathrm{Ca}^{2+}$ antagonists ( $\mathrm{Li}$ et al., 2001). Therefore, it is possible that $\mathrm{Sm}$ competes with $\mathrm{Ca}^{2+}$ by interacting with the biological membrane and with various types of calcium receptors.

\section{REFERENCES}

Abramczuk JW (1985). The effects of lanthanum chloride on pregnancy in mice and on preimplantation mouse embryos in vitro. Toxicology 34: 315-320. http://dx.doi.org/10.1016/0300-483X(85)90142-8

Buccigross JM and Nelson DJ (1986). EPR studies show that all lanthanides do not have the same order of binding to calmodulin. Biochem. Biophys. Res. Commun. 138: 1243-1249. http://dx.doi.org/10.1016/S0006-291X(86)80416-8

Chen J, Xiao HJ, Qi T, Chen DL, et al. (2015). Rare earths exposure and male infertility: the injury mechanism study of rare earths on male mice and human sperm. Environ. Sci. Pollut. Res. Int. 22: 2076-2086. http://dx.doi.org/10.1007/ $\underline{\text { s11356-014-3499-y }}$

China National Standardization Management Committee (CNSMC) (2003). National standards of the People's Republic of China: Mice sperm abnormality test. (No. GB15193.7-2003)

D'Agostino RB, Lown BA, Morganti JB and Massaro EJ (1982). Effects of in utero or suckling exposure to cerium (citrate) on the postnatal development of the mouse. J. Toxicol. Environ. Health 10: 449-458. http://dx.doi. org/10.1080/15287398209530267

Finney DJ (1978). Statistical Methods in Biological Assay. 3rd ed. Charles Griffin and Co. Ltd., London, 508.

Fujimori T and Jencks WP (1990). Lanthanum inhibits steady-state turnover of the sarcoplasmic reticulum calcium ATPase by replacing magnesium as the catalytic ion. J. Biol. Chem. 265: 16262-16270.

Goldstein JS and Jacobsen BS (1988). Rare earth elements in river waters. Earth Planet. Sci. Lett. 89: 35-47. http://dx.doi. org $/ 10.1016 / 0012-821 X(88) 90031-3$

Hirano S and Suzuki KT (1996). Exposure, metabolism, and toxicity of rare earths and related compounds. Environ. Health Perspect. 104 (Suppl 1): 85-95. http://dx.doi.org/10.1289/ehp.96104s185

Kamboj VP and Kar AB (1964). Antitesticular effect of metallic and rare earth salts. J. Reprod. Fertil. 7: 21-28. http:// dx.doi.org/10.1530/jrf.0.0070021

Lee WM, Tsang AY and Wong PY (1981). Effects of divalent and lanthanide ions on motility initiation in rat caudal epididymal spermatozoa. Br. J. Pharmacol. 73: 633-638. http://dx.doi.org/10.1111/j.1476-5381.1981.tb16798.x

Li FL, Wang YQ and Zhang ZY (2001). Study of samarium, ytterbium subcellular distribution in rat liver by enrichmental stability of isotope tracer method. Acta Sci. Nat. Univ. Pekinensis 37: 278-281.

Loscalzo J and Rabkin D (1986). The interaction of $\mathrm{Tb}^{3+}$ with the human platelet surface. Arch. Biochem. Biophys. 249: 237-242. http://dx.doi.org/10.1016/0003-9861(86)90579-5 
Marzec-Wróblewska U, Kamiński P, Łakota P, Ludwikowski G, et al. (2015). Determination of Rare Earth Elements in Human Sperm and Association with Semen Quality. Arch. Environ. Contam. Toxicol. 69: 191-201. http://dx.doi. org/10.1007/s00244-015-0143-x

Morganti JB, Lown BA, Stineman CH and Massaro EJ (1978). Cerium tissue/organ distribution and alterations in open field and exploratory behavior following repeated exposure of the mouse to citrate complexed cerium. Gen. Pharmacol. 9: 257-261. http://dx.doi.org/10.1016/0306-3623(78)90045-9

Triggle CR and Triggle DJ (1976). An analysis of the action of cations of the lanthanide series on the mechanical responses of guinea-pig ileal longitudinal muscle. J. Physiol. 254: 39-54. http://dx.doi.org/10.1113/jphysiol.1976.sp011219

Weiss GB (1974). Cellular. pharmacology of lanthanum. Annu. Rev. Pharmacol. 14: 343-354. http://dx.doi.org/10.1146/ annurev.pa.14.040174.002015

World Health Organization (WHO) (1999). WHO laboratory manual for the examination of human semen and spermcervical mucus interaction. 4th edn. Cambridge University Press, Cambridge.

Zhang DY, Shen XY, Ruan Q, Xu XL, et al. (2014). Effects of subchronic samarium exposure on the histopathological structure and apoptosis regulation in mouse testis. Environ. Toxicol. Pharmacol. 37: 505-512. http://dx.doi. org/10.1016/j.etap.2014.01.007 